INTERNATIONAL JOURNAL FOR

HISTORY, CULTURE AND MODERNITY

www.history-culture-modernity.org

Published by: Uopen Journals

Copyright: () The Author(s).

Content is licensed under a Creative Commons Attribution 4.0 International Licence

eISSN: 2213-0624

\title{
More than Fashionable Concepts? Risk, Security and Resilience in Modern History
}

Amerigo Caruso and Birgit Metzger

HCM 7: 301-320

DOI: $10.18352 / \mathrm{hcm} .514$

\begin{abstract}
For a long time, historians have written about topics that include questions relating to a given society's management of threats and risks. However, they did not use 'risk' as a category of analysis. Similarly, historians have extensively researched revolutions, social conflicts and disruptive events without elaborating a conceptual framework for security or resilience, and without historicizing these concepts. Since the turn of the millennium, the situation has changed fundamentally and risk, security and resilience have become new buzz words in historical research. These elastic concepts seem to provide the right degree of abstraction, interdisciplinary theory and contemporary relevance that historians need for their work. This article sheds light on how the notions of risk, security and resilience emerged, spread and influenced our present understanding of history and historiography. To what extent does this indicate a changing perspective in historiography? Or do recent developments in the field point to the reinvention of interpretative traditions using more fashionable concepts?
\end{abstract}

Keywords: historiography, modernity, resilience, risk, security

\section{Introduction}

In the last two decades, contemporary debates and theoretical reflections across several disciplines have contributed to drawing 
historians' attention to issues of risk, security and resilience. These issues all involve the perception of threats, uncertain futures and the management of risks. ${ }^{1}$ Historically, the interest in security and risk prevention peaked after periods of turmoil such as the Napoleonic Wars, or in the aftermath of natural disasters. The importance of risk, security and resilience increased during the Cold War and, more recently, in the post-9/I I world. The proliferation of crises (the global financial crisis of 2007-2008, the European debt crisis, the intensification of terrorist attacks, the Syrian civil war and the global refugee crisis) consolidated the importance of risk, security and resilience studies.

There are at least three reasons why the notions of risk, security and resilience are attractive for historians. First, they play a crucial role in current political discourse and, for this reason, draw public attention and give access to academic positions and research funding. Second, historians use the concepts for theoretical inspiration. Third, they are deeply linked with notions of time and changing perceptions of the future, topics that have regained momentum in recent historiography. ${ }^{2}$ Despite the fact that the notions of risk, security and resilience evolved within different academic disciplines and can be approached in different ways, there is shared interest in threat perceptions and strategies to cope with real or potential threats and with their impact on societies. This interest offers a common ground.

In this article, we give an account of current historical research on risk, security and resilience. We will explore the programmatic elaboration of this rapidly growing field of studies and discuss the empirical results by comparing large-scale research programmes on risk, security and resilience in historical perspective. What are the objectives of this research, which topics are highlighted and why? What do the conceptions of risk, security and resilience offer to historians, and what might they learn from them? We argue that there is a common interest, not just in processes of modernization, especially state building, cultures of prevention, and the increasing importance of scientific knowledge, but also in changing perceptions of time, especially the future. In the following, we provide several possible answers to the open-ended question about the extent to which studies on risk, security and resilience can reassess traditional narratives on modernity and historical discontinuity. 


\section{From 'Late-Comers' to Overburdened Words?}

For a long time, historians have written about topics relating to the management of threats and risks. They have studied, for example, the consequences of urban floods and fires, as well as food crises and epidemics; but they did not use 'risk' as a category of analysis. ${ }^{3}$ Similarly, historians have traditionally written about war, diplomacy, revolution and international security systems, but without developing a conceptual framework for security or resilience and without historicizing these concepts. The concepts of risk, security and resilience are not new. That of risk, for example, originated in the field of maritime history, and its use can be traced back to the Middle Ages. Risk was a key notion in the emerging insurance business in the early modern period, and it was closely related to health issues during the Industrial Revolution. Recent studies emphasize that the improvement of insurance methods and the development of risk regulation regimes and safety responsibilities were a fundamental precondition for the modern organization of society and the rise of capitalism. ${ }^{4}$ Since the I 950 os, the concept of risk has been applied to different aspects of society, for example frequent crop failures, the development of the welfare state and the trivializing of information in mass media. ${ }^{5}$

In the I980s, sociologists became increasingly involved in risk research, most prominently Ulrich Beck, Niklas Luhmann and Anthony Giddens. Beck's Risk Society was published just a few months after the nuclear disaster at Chernobyl in April I986. This tragically timed book became an international bestseller, and the thesis of Risk Society had an immediate impact on research questions in the field of environmental history, as well as in the history of technology. However, the term has been deployed with growing frequency in historical research only in the past two decades. The development of notions of security has followed roughly the same pattern. The term security already emerged as a key concept in political discourse during the seventeenth century and became even more prominent after the Congress of Vienna in the early nineteenth century and in the interwar years (I9I9-I939). ${ }^{6}$ Again, it was the Cold War and the so-called War on Terror after the turn of the millennium that stimulated more interest in security studies. ${ }^{7}$ Recently, scholars such as Eckart Conze have also highlighted the potential of the concept of securitization for historical research on state building and the communication of security issues. ${ }^{8}$ 
While security and securitization emerged from the fields of political science and international relations, the wave of resilience thinking has advanced from its origins in psychology and ecology to become a relevant topic discussed across a wide range of disciplines. Resilience is a more recent concept than risk and security and now plays a major role in the fields of anthropology, human geography, sociology, and, as of late, historiography. ${ }^{9}$

An indication of the state of affairs in 2019 illustrates this. In the past few years, several vast research projects relying on a single specific concept or a combination of the conceptual frameworks of risk, security and resilience have been founded by major research foundations all over Europe. The German Research Foundation (DFG) is currently funding the Collaborative Research Centres 'Threatened Orders - Societies under Stress' at the University of Tübingen and 'Dynamics of Security: Types of Securitization from a Historical Perspective' at the Universities of Marburg and Gießen. In addition, the DFG is funding the research group 'Resilience: Phases of Societal Upheaval in Dialogue between Medieval Studies and Sociology', hosted by the University of Trier. Other major German research foundations, such as the Leibniz Research Alliance and the Gerda Henkel Foundation, are currently supporting research programmes that are closely related to the field of risk, security, and resilience studies, such as 'Crisis in a Globalised World' at the Peace Research Institute in Frankfurt and 'Security and Future' at the Centre for Literature and Culture studies in Berlin. ${ }^{\text {Io }}$

The booming research on risk, security and resilience is not exclusively a German phenomenon. The Stockholm Resilience Centre, founded in 2007 , focuses on sustainable development and also conducts historical research. In France, the research programme 'History of Industrial Accidents and Risks' brought together a group of international researchers in order to gain a better understanding of the rise of industrial risk during the Industrial Revolution. ${ }^{I I}$ The Swiss National Science Foundation is currently funding the project 'Global Cultures of Risk', which examines the institutional and cultural conditions of globalization through the perspective of the history of insurance. This project is hosted by the Universities of Basel and Hull, and this fact underlines once more the international relevance of current research on risk, security, resilience, and related topics. Last but not least, the European Research Council (ERC) is contributing to this trend in the humanities. Among many other ERC grants related to risk, 
security and resilience, there are three particularly interesting historical research projects established after 20I4. Two of them are hosted by the University of Utrecht: the project 'Securing Europe, Fighting its Enemies', which examines the making of a security culture in Europe in the long nineteenth century, and the project 'Coordinating for Life', which analyzes the success and failure of Western European societies in dealing with crises and disasters in the early modern period. Finally, the ERC project 'Disasters, Communication and Politics in SouthWestern Europe', hosted by the University of Naples, is investigating the development of emergency response policies in early modern Italy and Spain.

This brief overview of recent research projects demonstrates the rapidly increasing interest of historians in risk, security and resilience across a number of European universities and research institutions. It reflects the general tendency towards the internationalization of research as well as the growing importance of interdisciplinary theory.

On the following pages, we will explore in more depth some current research and recent publications that have emerged from this booming field of studies. We will examine the changing perspectives and, by contrast, the persistence of schools of thought related to these new research paradigms. How and to what extent are risk, security and resilience merely new labels for some of the most popular issues of historians, such as revolution, modernization or crisis? If we follow Reinhart Koselleck, the concepts of revolution, change, fate, progress and development are complementary to the new idea of history, which emerged as a result of an alteration of the concept of time during the transitional period between the eighteenth and the nineteenth century (Sattelzeit). ${ }^{12}$ Are risk, security and resilience the result of contemporary concepts of history that have arisen since the turn of the millennium?

\section{Risk and Threat: Dealing with Uncertain Futures}

The notion of risk refers to potential harmful events in the future. It can apply to many different phenomena in different fields of human activity, including technology, economy, social relations and the environment. The expectation of something that might happen in the future and its consequences and the uncertainty about what will really happen are constitutive of the notion of risk. The concept of risk also implies 
the idea of being able to shape the future, and that means being able to decide whether to take a specific risk or not. ${ }^{13}$ Thus, risk depends on decision-making related to the future and on dealing with the future's contingencies. ${ }^{14}$

According to Ulrich Beck, a new type of risk production and a new way of dealing with risks emerged in late modernity. This moment of crucial change regarding risk production, perception and management took place in the I970s. Even though Beck had a realistic understanding of risks, he acknowledged that they are 'open to social definition and construction' through communication. ${ }^{15}$ This tension between cultural constructions on the one hand and their actual material and physical manifestation on the other is inherent to the notion of risk. Beck was especially interested in a new kind of risk resulting from modernization that demands a new form of risk management. Other authors assume that there is rather a rising demand for security within modern societies. ${ }^{16}$ Both interpretations highlight a rising awareness of risks and security issues in contemporary societies that has resulted in an increasing need to negotiate about threats and to create institutions in order to reduce and to manage these risks.

Beck's theories had a widespread but controversial impact among historians. ${ }^{17}$ They initially historicized Beck and his analysis in the context of the I970s and I980s, when industrial modernity and the economic boom of the post-war era went through a difficult patch and the belief in progress and modernity was undermined in public discourse. ${ }^{18}$ Even though historians focused principally on risk perception and communication, environmental and social historians also looked at the materiality of risks. They pointed out that the risks produced in modern societies by science and technology are not that new. Historians such as Franz-Josef Brüggemeier and Jean-Baptiste Fressoz clearly demonstrated that the risk of death or illness because of environmental pollution, workplace accidents or traffic accidents was extremely high in late nineteenth-century Europe, whereas these risks were on the decline at the beginning of the I970s. ${ }^{19}$ Another criticism is directed at Beck's claim about the democratization of risk. ${ }^{20}$ Historians analyzing disasters and accidents pointed out that those who are or have been socially or materially marginalized are still more likely to be affected by a social or technological risk or disaster.

The impact of the risk society on the development of modern governance and state building is a major area of interest of current 
research programmes on risk and security. One of them, the Collaborative Research Centre 'Threatened Orders', prefers the term 'threat' to risk but shares some common assumptions and approaches with the historiography of risk. The participating scholars are interested in the question of what happens to social cohesion when society's members perceive its structuring elements as threatened by something or someone. The core question of the collaborative research programme concerns the resulting uncertainty about the future. Order is understood as the paradigm that shapes and reshapes social relations and institutions as well as the expectations and actions of society's members. When an order is threatened, options to act in the future become uncertain; members of that order perceive their routines as in question and think that they cannot rely on each other. ${ }^{21}$ The research centre aims at historicizing the contemporary diagnosis of crises and understanding the modes of social change. Instead of master narratives, they look for gradual and openended developments and assume that there are premodern elements in modernity, just as there are modern elements in pre-modernity. ${ }^{22}$ This means that there is a fundamental difference between 'Threatened Orders' and most sociological theories about risk, as the latter always assume that there is a fundamental gap between modernity and premodernity and usually regard risk as characteristic of modernity, meaning socially differentiated societies. ${ }^{23}$

The project 'Threatened Orders' is embedded in a semantic field that contains the "contingency of negative events in the life of individuals and social developments'. ${ }^{24}$ The concepts of risk, security, uncertainty, vulnerability and resilience belong to this semantic field. ${ }^{25}$ By choosing to focus on the notion of threat, the participating scholars take the perspective of those who are or feel confronted by something or someone. According to Niklas Luhmann, risk refers to a possibility in the future resulting from our decisions, whereas threat is used when there is in fact a danger that can cause damage independently of our own previous decisions. ${ }^{26}$ The notion of threat places the subject in the position to react to a given situation, whereas risk also includes a proactive part: one decides to take a risk because it also includes the possibility of chance and success. However, the scholars of 'Threatened Orders' are also exploring the close relationship between threat and chance. When an order is threatened, it becomes destabilized and receptive to new ideas and opportunities. It is also a question of perspective, for what may be a threat to one person can be an opportunity for another. ${ }^{27}$ 
Although the Tübingen scholars claim that the notion of threat is used in a neutral way, ${ }^{28}$ the attribute 'threatened' implies that the object in question is in need of protection or preservation. While these scholars seem to privilege social change, researchers who study race relationships in the US suggest a critical approach: the repeated threatening of a regime can contribute to its stabilization because those who are interested in preserving the social order are motivated to defend it and thus adapt it to challenges. ${ }^{29}$ Communicating about potential future events that are perceived as negative, as a threat, can help either to legitimize an existing regime or to destabilize it. This leads to the questions of when and why a social order can become destabilized and thus open to fundamental social change. 'Threatened Orders' shares some basic ideas of risk research: for instance, the idea that the consequences of existential threats such as disasters or social conflicts can bring to light structures of societies that are usually hidden, thereby making them negotiable and thus apparent.

\section{Historical Accounts of Security and Securitization}

Risk and threat on the one hand and security on the other are closely related to each other as counterparts. They take specific perspectives on similar questions, such as the importance of 'looking forward' and communicating about threats in modern history. ${ }^{30}$ According to the Copenhagen school of security studies, the discourse of securitization has to fulfil three criteria: It '(I) claims that a referent object is existentially threatened, (2) demands the right to take extraordinary countermeasures to deal with that threat, and (3) convinces an audience that rule-breaking behaviour to counter the threat is justified. ${ }^{31}$ Historians generally aim at historicizing theories and conceptions, and this is an important corrective for rather 'static' accounts of security in political science..$^{32}$

'Dynamics of Security' and 'Securing Europe', the two major research projects on security, have chosen a broad definition of this concept, including not only ideas and practices but also 'cultures' of security. Research on security examines the materialization of threats as well as their perceptions; it deals with short-term answers to urgent security problems and with long-term transformations of cultures of security. Eckart Conze has suggested that the notion of securitization 'provides answers on how security problems emerge and why societies 
perceive certain issues as relevant in terms of security'. ${ }^{33} \mathrm{He}$ emphasizes that state building, the formation of social and cultural identities, and political communication are the main areas of research for historians working on security. ${ }^{34}$ Thus, the research programmes on risk and security share a common interest in perceiving and communicating about threats and dangers. They are also interested in examining the institutions that socialize risks or promise to prevent threats, particularly the modern state. In addition, actors beyond the state play an important role for the governance of risks and securitization, including voluntary actors at a local level, as well as commercial and transnational actors. ${ }^{35}$

Current research on security aims at providing new insights into the ongoing debate about the compatibility of liberty and security as well as the controversial relationship between security and violence on the one hand and the gradually dissolving boundaries between collective and individual security on the other. ${ }^{36}$ The historians Beatrice de Graaf and Eckart Conze recently pointed out that the Congress of Vienna was a fundamental turning point in the history of processes of securitization and new security cultures. ${ }^{37}$ After the French Revolution and the Napoleonic Wars, national security and international stability were perceived as overlapping. In early nineteenth-century Europe, security emerged as a key concept in political discourse, not only as a result of top-down, state-sponsored decisions but also as a consequence of the widespread debate on security in the expanding public sphere. Remarkably, 'Dynamics of Security' and 'Securing Europe' are both particularly interested in the transformations of the security approach during the nineteenth century: from the cooperative Vienna system, based on the balance of power, to the competing system of alliances in the Belle Époque. ${ }^{38}$ Other historians focus more on the change in the perception and meaning of security after the end of the Cold War. They trace the emergence of human security and the disappearing borders between internal and international security since the early I990s. ${ }^{39}$

Similar to the research on risk, current research on security aims at rethinking the traditional chronological and conceptual boundaries between modern and premodern history. Already in 1973, the sociologist Franz-Xaver Kaufmann pointed out that, as an analytical instrument, security is inseparably connected with narratives of historical time and the future. ${ }^{40}$ Following this approach, Cornel Zwierlein stresses that the history of security should not include only political institutions and social structures but also the history of time or, in other 
words, the historicization of security thinking. ${ }^{41}$ Whereas security studies tend to focus on political history and international relations, Zwierlein juggles with the dual conception of cultures of risk and security. He highlights that the improvement of insurance methods and obligations against some risks was a fundamental precondition for the modern organization of society and capitalism between the fifteenth and the nineteenth century. ${ }^{42}$ Both Zwierlein and Emily C. Nacol, as well as the previously mentioned research projects, use an extended concept of security that transgresses the political sphere. ${ }^{43}$ There is a tendency in research to emphasize the perception of uncertainty that creates new cultures of security and prediction. The historian Jamie L. Pietruska has demonstrated that contemporaries in late nineteenth-century America increasingly looked forward and established different prognostic methods in order to reduce 'the spectre of uncertainty'. ${ }^{44}$ The emerging culture of security and dealing with risks had a major impact not only on state building and capitalism but also on the changing perceptions of time and the future. This led to the 'first' discovery of the future even before the era of paradigmatic modernity in the nineteenth and twentieth century. 45

\section{From Response to Resilience: Another Buzzword for the New Millennium?}

According to the sociologist Ulrich Bröckling, whose studies are increasingly popular among historians, resilience ranks among the key concepts of the twenty-first century. ${ }^{46}$ Bröckling argues that resilience thinking is closely related to the changing perception of an (uncertain) future. Similarly to risk and security, resilience studies examine the development of macro- and micro-strategies for dealing with present and future threats. However, they adopt different approaches. ${ }^{47}$ Risk offers a way of thinking that makes future threats the objective of a rational, even mathematical logic that analyzes risk factors, probabilities and the possible extent of damages. On the basis of these reflections and calculations, one can choose to take a risk or not, to take out an insurance policy or to take some measure to minimize the effect of a probable future threat. Resilience thinking sheds light on a partly different process that consists in strengthening the ability of individuals or groups to persist and endure in the face of stress or an adverse environment. 
American sociologists began as early as the I990s to debate about the roots of resilience and the optimistic view of human nature inspired by this concept. ${ }^{4}$ In the past decades, resilience studies have constantly expanded their range of influence across different disciplines, including not only the fields of anthropology, human geography, psychology and sociology but also international studies, policy-making, and, quite recently, historiography.

In 2008, the Australian premier minister Kevin Rudd launched a political initiative aimed at making resilience a national priority and moving the Australian approach to emergency management from response to resilience. ${ }^{49}$ Ten years later, the Australian government is still highly interested in building resilience and dedicates significant budget resources to strengthening the country's resilience against natural disaster and economic shocks (\$690.9 million in the 20I8-I9 budget estimate)..$^{\circ}$ As in the case of risk and security, the availability of interdisciplinary theory and the public relevance of resilience has convinced a growing number of historians that resilience thinking might make a productive contribution to their vocabulary and research interests. ${ }^{5 I}$ The differentiation between coping, adaptive, and transformative capacities is one important step to theoretically developing and methodologically implementing the resilience approach in so many different disciplines, particularly in history. New historical research on resilience relies on three pillars: persistence, adaptability and transformability. ${ }^{52}$ In addition, historians have adopted the notion of the adaptive cycle. According to this theory, 'resilient systems are ones that successfully navigate all stages of growth, development, collapse, and reorientation'. ${ }^{53}$

Despite the widespread debate on resilience, there is no generally accepted definition of this concept. In history, we can use the term of resilience in a narrow sense to refer to 'the return rate to equilibrium upon a perturbation' ${ }^{54}$ For instance, resilience can be used to examine the new international order established after the fall of Napoleon in I8I5. A second way to use the concept of resilience in history is to put the research focus on bouncing-back processes after major critical situations such as political revolutions, military invasions or economic crises. The resilience approach allows an understanding, for instance, of how exile and migration were not only defensive strategies but also, and much more so, adaptability-strengthening processes in the context of the transnational circulation of ideas and modern state building. In 
history as in other disciplines, resilience seems to be an approach that values individual, social and political continuity and the ability to adapt to difficult environments instead of changing the environment. It means more than merely bouncing back after a crisis or returning to the status quo after a revolution. Resilience explores 'the capacity to persist in the face of change'. 55

The research group 'Resilience: Phases of Societal Upheaval in Dialogue between Medieval Studies and Sociology' is one of the first major research programmes on resilience to be established in the field of history. Hosted by the University of Trier, the group implements an analytical framework aimed at describing 'historical processes in terms of resilience'. ${ }^{56}$ Inspired by a combination of sociological theory and empirical research on medieval history, these scholars developed a terminology to apply the conception of resilience in historical research. ${ }^{57}$ Four fields of research are considered of special importance: (I) resilience processes, (2) resilience strategies, (3) resilience dispositions and (4) resilience resources. Resilience processes include practices and ideas of adaptability and conservation which help social groups or individuals to maintain their identity in the face of major threats. Resilience strategies are intents, expectations and methods that aim at stabilizing social groups or institutions to help them cope with disasters and shocks. The notions of processes and strategies seem quite similar, though resilience processes refer to long-term transformations. Resilience dispositions are incorporated knowledge and deep-seated experiences that are (re)activated to challenge instability. Finally, norms and values as well as economic and political capacities can generate resilience resources for individuals and communities. Historians are using the concept of resilience as a means of reconsidering the history of ruptures and revolutionary events beyond teleological interpretations. They aim at elaborating new analytical criteria and chronological borders to examine continuity, especially continuity through change.

\section{Conclusions}

The strongest argument in favour of the use of risk, security and resilience in history is the challenge these concepts pose to teleological explanations by stressing the role of contingency and multiple paths to modernity. By investigating both cultural constructions and material 
manifestations of threats, historical research on risk, security and resilience may help us to understand the diversity of contested futures in the course of history. All three concepts are suitable for bundling a multiplicity of subjects in a specific perspective that focuses on the perception of threats to the human body, property and social order..$^{58}$ That is one reason why interdisciplinary work and reflections are well implemented in this field of research. In addition, it integrates different subdomains of history: economic history as well as the history of the environment and natural disasters, medical history as well as the traditionally dominant field of political history. However, the history of emotions and that of gender, which are among the most broadly discussed topics in current historiography, seem to be marginal in these current programmes. ${ }^{59}$

Another strength of the concepts of risk, security and resilience is that they seem to value long-term transformations. Ulrich Beck had the brilliant idea of using the paradigm of risk to historicize modernity. However, historians do that in another way. Research on risk, security and resilience aims at challenging traditional chronological and conceptual boundaries between modern and premodern history. The scholars involved tend to rethink turning points to shed new light on political (dis)continuity and social change. Time is one of the key categories related to risk, security and resilience, as these conceptions are directed at the future. This connects the research described here to the temporal turn that historiography is currently experiencing. Risk and security studies examine, for example, the changing perceptions of historical time and the invention of the future.

It seems that these concepts help researchers to look with fresh eyes on well-known topics and questions about the birth of the modern world, but they do not dismantle the paradigm of modernization and modernity. Indeed, risk, security and resilience are related in several different ways to narratives of modernity. Are these notions as neutral and open-ended as the projects we have presented in this article suppose? Risk, security and resilience are objects of historical research and at the same time politically influential signatures in our contemporary world. The research programmes follow a trend in contemporary thinking that is based on the idea of replacing optimism with pragmatism and on concerns about stability and adaptability. It seems that Benedetto Croce's philosophy of history and his criticism of positivist historiography can partly explain the unprecedented intensification of the study of risk, security and resilience. Croce distinguished between 
chronicle (act of will) and history (act of thought). He described chronicle as 'past history' and history as 'contemporary history', which is, as an act of thought, inseparably linked with our present consciousness. ${ }^{60}$ Risk, security and resilience thinking clearly emerged from our present perceptions, fears and expectations. This can be a problem if it leads to presentism, namely a regime of historicity that tends to interpret the past in presentist terms and overemphasize the importance of the contemporary period. ${ }^{61}$

Since the pioneering work of the Annales school, historians have increasingly used theories in their research. However, it does not often occur that historians systematically discuss their empirical results in order to re-elaborate theories. Historians are always looking for middle-range concepts and theories that are fuzzy enough to enable them to bundle various diverging case studies over time and over space but provide analytical instruments that make comparisons and more general reflections possible and meaningful. Koselleck famously pointed out that 'only theory transforms our work into historical scholarship'. ${ }^{62}$ Risk, security and resilience seem to provide frameworks with the right degree of theoretical abstraction, interdisciplinarity and contemporary relevance. For these reasons, historians are currently using these concepts to 'transform' their work into historical scholarship.

\section{Notes}

I On the partial overlapping of risk and security studies, see Herfried Münkler, 'Strategien der Sicherung: Welten der Sicherheit und Kulturen des Risikos. Theoretische Perspektiven', in Münkler et al (eds), Sicherheit und Risiko. Über den Umgang mit Gefahr im 2I. Jahrhundert (Bielefeld, 20 I0) I I-34. More recently, not only studies on risk, but also on resilience and prevention have been considered as part of this broad field of security studies. See Eckart Conze, Geschichte der Sicherheit. Entwicklung Themen - Perspektiven (Göttingen, 2018) I07-26.

2 See Berber Bevernage and Chris Lorenz, 'Breaking up Time - Negotiating the Boarders between Present, Past and Future. An Introduction', in Chris Lorenz and Berber Bevernage (eds), Breaking up Time - Negotiating the Boarders between Present, Past and Future (Göttingen, 20I3), 7-38. On the temporal turn, see also: Elke Seefried, 'Reconfiguring the Future? 
Politic and Time from the I960s to the I980s. Introduction', Journal of Modern European History I3:3 (2015) 306-I6.

3 Arwen P. Mohun, 'Constructing the History of Risk. Foundations, Tools, and Reasons Why', Historical Social Research / Historische Sozialforschung 4I: I (20I6) 30-47, at 34.

4 See Cornel Zwierlein, Der gezähmte Prometheus. Feuer und Sicherheit zwischen Früher Neuzeit und Moderne (Göttingen, 20 I I); Emily C. Nacol, An Age of Risk. Politics and Economy in Early Modern Britain (Princeton, 2016); Julia Moses, The First Modern Risk. Workplace Accidents and the Origins of European Social States (Cambridge, 20 I 8).

5 Michelle Burge McAlpin, 'Dearth, Famine, and Risk: The Changing Impact of Crop Failures in Western India, I870-1920', The Journal of Economic History 39:I (I979), I43-57; Lutz Raphael, Poverty and Welfare in Modern German History (Oxford, 2016).

6 See Werner Conze, 'Sicherheit, Schutz', in Otto Brunner et al (eds), Geschichtliche Grundbegriffe. Historisches Lexikon zur politisch-sozialen Sprache in Deutschland, Vol. 5 (Stuttgart, I984) 83 I-62. See also Luise Schorn-Schütte, 'Sicherheit als Begriff und Phänomen in der Europäischen Frühen Neuzeit', in Christoph Kampmann and Ulrich Niggemann (eds), Sicherheit in der Frühen Neuzeit. Norm - Praxis - Repräsentation (Cologne, 20I3), 43-6.

7 For example Zeithistorische Forschungen/Studies in Contemporary History, 7:2 (2010) https://zeithistorische-forschungen.de/2-20I0; this special issue edited by Tatjana Tönsmeyer and Annette Vowinckel was one of the first efforts to deal systematically with the history of security, security perceptions and risk.

8 Eckart Conze, 'Securitization. Gegenwartsdiagnose oder historischer Analyseansatz?', Geschichte und Gesellschaft 38:3 (2012), 453-67.

9 The scientific citation indices show a constant increase of scientific publications on resilience: from less than Ioo citations in 1995 to more than 20,000 in 2015. See Carl Folke, 'Resilience (Republished)', Ecology and Society 2 I:4 (2016).

Io Other important research programmes on similar topics can be mentioned: the graduate school 'Kontingenzbewältigung durch Zukunftshandeln' at the University of Duisburg-Essen and the Collaborative Research Centre 'Discourses of Weakness and Resource Regimes' at the University of Frankfurt (SFB I095).

I I See also Alain Chatriot, 'Gouverner et administrer les risques', Histoire@ politique, 36:3 (2018). 
I 2 Koselleck, Futures Past, 4.

I3 Francois Ewald, 'Die Rückkehr des genius malignus: Entwurf zu einer Philosophie der Vorbeugung', Soziale Welt 49: I (I998) 5-24; Ortwin Renn et al, Risiko. Über den gesellschaftlichen Umgang mit Unsicherheit (Munich, 2007) 20-I.

I4 This is the crucial theme of the graduate program at the University of Duisburg-Essen. See Frank Becker et al (eds), Die Ungewissheit des Zukünftiges (Frankfurt and New York, 2016).

I5 Ulrich Beck, Risk Society. Towards a new modernity (London, I992), 23.

I6 See Franz-Xaver Kaufmann, Sicherheit als soziologisches und sozialpolitisches Problem. Untersuchungen zu einer Wertidee hochdifferenzierter Gesellschaften (Stuttgart, I973).

I7 Along with Beck's theory, new research projects on risk also have similarities with the ideas of risk developed by Mary Douglas and Aaron Wildavsky in the I980s. These two scholars interpreted risk as a socially and culturally constructed entity and compared premodern and contemporary perceptions of risk. Mary Douglas and Aaron Wildavsky, Risk and culture: An essay on the selection of technological and environmental dangers (Berkeley, I983).

I8 Anselm Doering-Manteuffel and Lutz Raphael, Nach dem Boom: Perspektiven auf die Zeitgeschichte seit I970 (Göttingen, 2008) 85-9I.

I9 See, for example: Franz-Josef Brüggemeier, Schranken der Natur. Umwelt, Gesellschaft, Experimente (Essen, 20I4) 349-50; Soraya Boudia and Jas Nathalie, 'Risk and Risk society in Historical Perspective', History and Technology 23:4 (2007) 3 I7-3 I; Jean-Baptiste Fressoz, 'Beck Back in the Nineteenth Century: Towards a Genealogy of Risk Society', History and Technology 23:4 (2007) 333-50.

20 Beck, Risk Society, 36. For some criticism, see Brüggemeier, Schranken der Natur, 350.

2 I For a programmatic description of the project, see its website: http:// www.uni-tuebingen.de/en/research/core-research/collaborative-researchcenters/sfb-923/scientific-profile.html (accessed 2 I July 20I8).

22 Ewald Frie, 'Bedrohte Ordnungen zwischen Vormoderne und Moderne. Überlegungen zu einem Forschungsprojekt', in Klaus Ridder et al (eds), Die Aktualität der Vormoderne. Epochenentwürfe zwischen Alterität und Kontinuität (Berlin, 2013) 99-I09.

23 Stefan Kaufmann and Ricky Wichum, 'Risk and Security: diagnosis of the present in the context of (post-) modern insecurities', Historical Social Research, 4I (2016), 48-69, at 66-7. 
24 Fabian Fechnter, Tanja Granzow, Jacek Klimek, Roman Kraielicki, Beatrice von Lüpke, Rebekka Nöcker, 'We are gambling with our survival', in Ewald Frie et al (eds), Aufruhr - Katastrophe - Konkurrenz - Zerfall. Bedrohte Ordnungen als Thema der Kulturwissenschaften (Tübingen, 20I4), I4I-74, at I42.

25 Frie, 'Bedrohte Ordnungen', I07.

26 Niklas Luhmann, 'Risiko und Gefahr', Soziologische Aufklärung 5 ( I990) I3 I-69.

27 Frie and Nieswand, 'Zwölf Thesen zur Begründung eines Forschungsbereiches', Journal of Modern European History I 5: I (2017) 5-I9; Ewald Frie and Mischa Meier, 'Bedrohte Ordnungen. Gesellschaften unter Stress im Vergleich', in Frie et al, Aufruhr-Katastrophe-Konkurrenz - Zerfall, I-29, at 22.

28 Fechnter et al, We are gambling with our survival, I66.

29 Astrid Franke and Nicole Hirschfelder, "Mycomb was itself again": Wandel und Resilienz einer ungerechten Ordnung', in Frie et al, AufruhrKatastrophe - Konkurrenz - Zerfall, I97-228, at 22 I-2.

30 See Herfried Münkler, 'Die Untrennbarkeit von Sicherheit und Risiko - Über die Komplementarität von Strategien und Mentalitäten in Sicherheitsregimen und Risikomanagement', Frank Becker et al (eds), Die Ungewissheit des Zukünftigen. Kontingenz in der Geschichte (Frankfurt, 20I6) i6I-84.

3I Rens van Munster, 'Securitization', in Oxford Bibliographies (last modified 26 June 20I2; http://www.oxfordbibliographies.com/view/document/ obo-9780I99743292/obo-9780I99743292-009I.xml, accessed o3 August 20I8).

32 Christopher Daase, 'Die Historisierung der Sicherheit. Anmerkungen zur historischen Sicherheitsforschung aus politikwissenschaftlicher Sicht', Geschichte und Gesellschaft 38:3 (2012) 387-405.

33 Eckart Conze, 'Securitization. Gegenwartsdiagnose oder historischer Analyseansatz?', Geschichte und Gesellschaft 38:3 (2012), 453-67.

34 Ibid.

35 Tom Crook, Mike Esbester, 'Risk and the History of Governing Modern Britain, c. I800-2000', in Tom Crook and Mike Esbester (eds), Governing Risks in Modern Britain. Danger, safety and accidents c.I800-2000 (Basingstoke, 20I6), I-26.

36 See Horst Carl, 'Einleitung in die Sektion: Sicherheit vor Gewalt Sicherheit durch Gewalt', in Christoph Kampmann and Ulrich Niggemann (eds), Sicherheit in der Frühen Neuzeit. Norm - Praxis - Repräsentation 
(Cologne, 2013), 265-72; noticeable is also Angela Marciniak, Politische Sicherheit. Zur Geschichte eines umstrittenen Konzepts (Frankfurt, 2015). On security and liberty, see Quentin Skinner, 'Liberty and Security: The Early-Modern English Debate', in Christoph Kampmann and Ulrich Niggemann (eds), Sicherheit in der Frühen Neuzeit. Norm - Praxis Repräsentation (Cologne, 2013) 30-42.

37 See Beatrice de Graaf, 'Introduction', Beatrice de Graaf (ed.), Securing Europe after Napoleon. I8I5 and the New European Security Culture (Cambridge, 2018).

38 Eckart Conze, 'Konzertierte Sicherheit: Wahrnehmung und Wirkung des Wiener Kongresses im I9. und 20. Jahrhundert', Journal of Modern European History I3 (20 I 5) 439-46. See also Christopher Daase, 'Wandel der Sicherheitskultur', Aus Politik und Zeitgeschichte 50 (2010) 9-16. This approach develops the insights of Werner Conze's article in the Geschichtliche Grundbegriffe, which described the change in meaning of the existing security concept during the Sattelzeit.

39 See Cornel Zwierlein, 'Sicherheitsgeschichte. Ein neues Feld der Geschichtswissenschaften', Geschichte und Gesellschaft 38:3 (2012) 365-86.

40 See Kaufmann, Sicherheit.

4I Cornel Zwierlein, 'Grenzen der Versicherbarkeit als Epochenindikatoren? Von der europäischen Sattelzeit zur Globalisierung des I9. Jahrhunderts', Geschichte und Gesellschaft 38:3 (2012) 423-52, at 423. The focus on security as an analytical instrument for rethinking traditional chronological boundaries is also a key element in Zwierlein's monograph on the omnipresent danger of fires in early modern cities. See Zwierlein, Der gezähmte Prometheus.

42 See also Moses, The first modern Risk; Nicolai Hannig, Kalkulierte Gefahren: Naturkatastrophen und Vorsorge seit I80o (Göttingen, 20I9).

43 Nacol, Age of Risk.

44 Jamie L. Pietruska, Looking Forward: Prediction and Uncertainty in Modern America (Chicago, 2017).

45 See Christoph Kampmann and Ulrich Niggemann, 'Sicherheit in der Frühen Neuzeit - Zur Einführung', in Christoph Kampmann and Ulrich Niggemann (eds), Sicherheit in der Frühen Neuzeit. Norm - Praxis Repräsentation (Cologne, 2013) I 2-27.

46 See Ulrich Bröckling, Gute Hirten führen sanft. Über Menschenregierungskünste (Frankfurt, 2017). 
47 See also Philippe Bourbeau and Juha Vuori, 'Security, Resilience and Desecuritization: Multidirectional Moves and Dynamics', Critical Studies on Security 3:3 (20 I 5) 253-68.

48 See R. Fox Vernon, 'A Brief History of Resilience. From Early Beginnings to Current Constructions', in Caroline Clauss-Ehlers and Mark Weist (eds), Community Planning to Foster Resilience in Children (New York, 2004) I 3-26.

49 Stephen Jenkins, 'Resilience: The New Paradigm in Disaster Management - An Australian Perspective', World Journal of Engineering and Technology 3 (2015) I 29-39.

50 See Australian Government, Department of Foreign Affairs and Trade, http://dfat.gov.au/aid/topics/investment-priorities/building-resilience/ Pages/building-resilience.aspx (accessed o6 June 2018).

5I Sabine Höhler argues that the most valuable asset of resilience studies is the availability of a strong interdisciplinary framework. See Sabine Höhler, 'Resilienz: Mensch - Umwelt - System. Eine Geschichte der Stressbewältigung von der Erholung zur Selbstoptimierung', Zeithistorische Forschungen/Studies in Contemporary History I I:3 (2014) 425-43.

52 See Lukas Clemens and Christoph Cluse, 'European Jewry around I400: Disruption, Crisis and Resilience - Problems and Research Perspectives', in Lukas Clemens (ed.) The Jews of Europe around I4OO: Disruption, Crisis, Resilience (Wiesbaden, 20I8), I-30. The idea that resilience incorporates continuous change as well as the 'capacity to adjust responses' and the ability 'to cross thresholds into new development trajectories' was introduced by Carl Folke. See Folke et al, 'Resilience thinking: integrating resilience, adaptability and transformability', Ecology and Society I5:4 (20IO), art 20.

53 Brian D. Fath et al, 'Navigating the adaptive cycle: an approach to managing the resilience of social systems', Ecology and Society 20:2 (20 I 5), art 24.

54 Folke, Resilience, 2.

55 Ibid., 2-3.

56 Clemens and Cluse, European Jewry, I 5.

57 See Martin Endreß and Benjamin Rampp, 'Resilienz als Perspektive auf gesellschaftliche Prozesse. Auf dem Weg zu einer soziologischen Theorie', Martin Endreß and Andreas Maurer (eds), Resilienz im Sozialen. Theoretische und empirische Analysen (Wiesbaden, 20 I 5), 35-55.

58 Among recent publications, Nicolai Hannig and Malte Thießen (eds), Vorsorgen in der Moderne. Akteure, Räume und Praktiken (Berlin, 
2017); Eva von Contzen et al (eds), Risikogesellschaften. Literatur- und geschichtswissenschaftliche Perspektiven (Bielefeld, 2018).

59 In Geschichte der Sicherheit, I66, Eckart Conze makes a plea for more integration of the history of emotion in security studies.

6o See Eugene Thomas Long, Twentieth-Century Western Philosophy of Religion 1900-2000 (Dordrecht, 2003) 246.

6I Lynn Hunt, 'Against Presentism', Perspectives on History 45 (2002), (https://www.historians.org/publications-and-directories/perspectives-onhistory/may-2002/against-presentism, accessed 03 August 2018). See also François Hartog, Regimes of Historicity: Presentism and Experiences of Time (New York, 2017).

62 Reinhart Koselleck, Zeitschichten. Studien zur Historik, (Frankfurt, 2000), 304.

\section{About the Authors}

Amerigo Caruso is Lecturer in Modern European History at Saarland University. His current research project investigates the resilience shown by political and social elites after disruptive events in different historical contexts, c. I800-I950. In his first book, Nationalstaat als Telos? Der konservative Diskurs in Preußen und Sardinien-Piemont I840-I870 (De Gruyter, 20 I7), he analyses the conservative discourse and the process of nation-building in mid-nineteenth-century Italy and Germany. Email: amerigo.caruso@uni-saarland.de

Birgit Metzger is Lecturer in Cultural and Media History at Saarland University. She was a postdoctoral researcher at the Freiburg Institute for Advanced Studies and the University of Strasbourg Institute for Advanced Study. Currently she is working on the reactions to, and the impact of, non-combat military accidents, comparing France and Germany in the twentieth century. In her PhD thesis, published as “Erst stirbt der Wald, dann Du!" Das Waldsterben als westdeutsches Politikum I978-I986 (Campus, 2015), she examined the environmental debate and politics in West Germany during the I970s and I980s. Email: birgit.metzger@uni-saarland.de 